\title{
特集「“治療可能な認知症（treatable dementia）” の現在一その可逆性を考えるー」
}

\author{
序文 \\ 金 野 倫 子 \\ 埼玉県立大学保健医療福祉学部共通教育科

\section{"Treatable Dementia: Current Situation and Challenges in Clinical Practices" Introduction} \\ Michiko Konno \\ Center for University-wide Education, Faculty of Health Sciences, Saitama Prefectural University
}

慢性, 進行性の全般性認知機能低下を来す認知症は, その原因となり得る疾患が優に 150 を超えると言われて いる．認知症は一般に進行性，不可逆性と捉えられてい るのに対して，一部の原因疾患は早期に発見介入するな らば，治癒ないし改善が望めるとされている。

進行麻疩等の臨床経験から, 認知症の一部は回復しう るという認識は, 精神医学では実際のところ 1930 年代 あたりから共有されていたと見受けられる。しかし， 1967 年 Hills らの正常圧水頭症の報告などがあり，1980 年の Cummings らによる「回復可能な認知症 (reversible dementia)」の提唱を経て,「治療可能な認知症 (treatable dementia)」の概念が成立してきたのは 1980 年代とされ ている。むしろこの用語の登場によって認知症一般は “不可逆的で治療不能”なものとして改めて定義される ようになったふしがある。

現在広く知られ定着している「治療可能な認知症」の 概念だが，どのような疾患が含まれるのか，どのように 診断がなされるのか，どの時点でどういった介入をすれ ばどこまで回復するのかについては医学の発展により変 化するため, 他方では不断に update していく必要があ る概念でもある。

一方で, 慢性・進行性・不可逆性の認知症と「治療可 能な認知症」との関係も変化しつつある。アルツハイマー 型認知症 (Alzheimer's disease: AD) を例にとると, 神経細 胞外 $\beta$ アミロイド沈着や神経細胞内異常リン酸化夕ウ蛋 白の凝集・蓄積といった病理過程に直接介入する疾患修 飾薬 disease modifying drug の開発が現在進んでいる。そ の進渉は当初の予想よりも緩徐ではあるが, $\mathrm{AD}$ を可逆 的で治療可能にする方向を目指すものであり，「治療可 能な認知症」との距離は少しずつ縮まっているといえる.

また， $\mathrm{AD}$ 治療薬の開発や治験の途中でわかってきた ことのひとつは, 神経病理レベルでは改善が見られても, 認知機能改善は必ずしも並行しないということである。

こういった問題や他の知見の蓄積によって, 研究の関心 の一部は“ADの病理過程においてどの時点までに介入
すれば認知機能は改善し可逆性の経過をとり得るのか” といった問いに向かっている。このような問いに対して も先の「治療可能な認知症」における可逆性についての 知見はヒントを与えると考えられる。

今回の特集では脳神経外科, 腎臓高血圧内分泌内科, 血液膠原病内科, 神経内科, 精神神経科から寄稿を頂 き, 各領域における「治療可能な認知症」について, 診 断と治療の実際を “可逆性”を中心として概括し解説し ていただいた。脳神経外科領域においては，手術によっ て慢性認知機能低下の改善が見込まれる疾患として正常 圧水頭症や慢性硬膜下血種があるが，今回は高齢者に多 い特発性正常圧水頭症 (idiopathic NPH: iNPH) について, 髄液排除試験後における症状改善の多様なパターン, シャント手術の時期による改善の違いなどが詳述されて いる。腎臓高血圧内分泌内科の領域における「治療可能 な認知症」としては甲状腺機能低下症が有名であるが, 今回は腎不全と認知機能低下をとりあげ，加えて透析中 の認知機能低下，更に透析と関連して糖尿病と認知症発 症リスクの関連を考察するという展望的な内容となって いる。血液膠原病内科の領域からは, コバラミン（ビタ ミン $\mathrm{B}_{12}$ ） 欠乏症による巨赤芽球性貧血をとりあげ，さ らに高齢者に少なからずみられる, 貧血症状のそしい潜 在性コバラミン欠乏症の診断と対応も付した詳説となっ ている。神経内科領域では中枢神経系にみられる感染症 について解説, 古典的な症状が出現しにくい高齢者にお いては認知症鑑別の際念頭におくべき疾患であることを 指摘，また中枢神経系が感染症という事態を受けた時に 精神症状はどのような経過を辿るのかについて概括して いる。精神神経科領域ではアルコール依存症の経過中に しばしば見られるウェルニッケコルサコフ症候群につい て, 概念の変遷, 複雑な病態生理, 治療とその予後につ いて概観している.

認知症診療に関わる者としては知っておきたいポイン トが散りばめられおり, 明日からの診療がより厚みを増 すと感じられる今回の特集である。 